\title{
A 3 year prospective study of survival rate of narrow diameter implants
}

\author{
Sung-Jo Lee 1 , Sae-Young Jung', Hyun-Seung Shin ${ }^{1 *}$, Jung-Chul Park', Young-Gyun Song ${ }^{1}$, In-Woo Cho' \\ 'Department of Periodontology, College of Dentistry, Dankook University, Cheonan, Republic of Korea \\ 2Department of Prosthodontics, College of Dentistry, Dankook University, Cheonan, Republic of Korea
}

Purpose: The purpose of present study was to retrospectively analyze the survival rate of narrow diameter implant less than $3.6 \mathrm{~mm}$ by initial stability and radiographic measurements. Materials and Methods: In total, 24 patients who received 38 narrow diameter implants ( $\leq 3.6 \mathrm{~mm}$ in diameter, $\geq 7 \mathrm{~mm}$ in length) were enrolled in this retrospective study. The cumulative survival rate was calculated and various factors were investigated according to the implant platform diameter, body diameter, length, position, concomitant use of guided bone regeneration in implant placement and final prosthesis type. Initial stability was investigated with implant stability quotient (ISQ) value. The mesial and distal marginal bone level (MBL) change was calculated with radiography. Results: The overall survival rate was $92.11 \%$. Mean ISQ value and MBL change of survival implants was 66.26 and $0.14 \pm 0.31 \mathrm{~mm}$, respectively. None of the implants with platform diameters larger than the body diameter failed. Conclusion: In conclusion, the findings of present study suggest that narrow diameter implant could be predictable treatment in narrow alveolar ridge. (J Dent Rehabil Appl Sci 2018;34(1):32-8)

Key words: narrow implant; survival rate; resonance frequency analysis

\section{서론}

치주질환, 근관 치료의 실패, 외상 등의 원인에 의한 과 도하게 흡수된 잔존골의 양과 형태는 표준 직경 임플란 트의 식립을 어렵게 하며 이를 극복하기 위해 수직, 수평 적 골 증대를 위한 골유도재생술이 동반되어 왔고 높은 성공률과 장기간의 양호한 예후가 보고되어왔다. ${ }^{1}$ 그러 나 골이식술을 동반한 치료의 경우 추가적인 수술 및 환 자의 불편감 증가, 치료 기간 및 비용의 증가, 합병증 발 생 가능성 증가 등의 부작용이 나타나게 된다. ${ }^{2}$ 이를 극 복하기 위한 대안으로 좁은 직경의 임플란트를 식립하는 것을 고려할 수 있다.

좁은 직경 임플란트의 기준은 명확하지 않으나, fifth

*Correspondence to: Hyun-Seung Shin

Assistant Professor, Department of Periodontology, Dankook University College of Dentistry, 119 Dandae-ro, Dongnam-gu, Cheonan, 31116, Republic of Korea Tel: +82-41-550-0263, Fax: +82-303-3442-7364, E-mail: perioshin@dankook.ac.kr Received: November 24, 2017/Last Revision: November 27, 2017/Accepted: January 2, 2018
ITI Consensus Conference에서 발표된 바에 따르면 역 사적으로 현재까지 가장 많이 연구되고 사용되었던 임플 란트의 직경은 $3.75-4.1 \mathrm{~mm}$ 로, 이 범위의 직경의 임플 란트가 통상적으로 표준 직경 임플란트로 규정되고 있 다. ${ }^{3.4}$ Klein 등은 $3.3-3.5 \mathrm{~mm}$ 의 직경을 갖는 임플란트의 경우 load-bearing되는 구치부를 포함한 모든 부위에서 성공적인 결과를 나타내었고, $3.0-3.25 \mathrm{~mm}$ 의 직경을 갖 는 임플란트의 경우 non-load-bearing의 단일치아 수복 에 한정하여 성공적인 결과를 나타냄을 보고하였다. 그 러나 $3.0 \mathrm{~mm}$ 미만의 직경을 갖는 임플란트의 경우 무치 악 부위 또는 non-load-bearing의 부위에서 사용되었다 보고되었으나 성공률은 명확하지 않다고 보고하였다. ${ }^{5}$

좁은 직경 임플란트는 짧은 치아간 폭경 및 치경부 직 
경이 좁은 치아의 적절한 emergence profile의 형성이 용 이하나, ${ }^{6}$ 작은 직경에 따른 파절 가능성, 임플란트 직경 과 교합면 넓이의 차이에 따른 cantilever effect 가능성, fixture의 좁은 골 유착 면적 등의 단점으로 기피되어 왔 다. ${ }^{7}$ 이를 극복하기 위해 platform 형태와 taper의 변형을 통한 골 유착도 개선, titanium과 혼합될 미량원소의 조 절 및 다양한 물질과의 합금으로 제작된 fixture를 통해 물성을 강화하는 등 많은 연구가 진행되어왔다. ${ }^{8}$

이번 연구에서 사용된 임플란트는 Sandblasting with Large grit and Acid etching (SLA)의 표면을 갖는 임 플란트(NR line, Dentium, Seoul, Korea)로, 통상적인 straight platform을 지닌 fixture와 fixture body보다 넓 은 형태의 tapered platform을 지닌 fixture의 두가지 형 태로 이루어져 있다. 해당 임플란트 중 fifth ITI Consensus Conference에서 발표된 좁은 직경 임플란트의 기준 에 부합되는 것은 platform 직경 $3.2 \mathrm{~mm}$ 에 body 직경 3.1 $\mathrm{mm}$, platform 직경 $3.6 \mathrm{~mm}$ 에 body 직경 $3.1 \mathrm{~mm}$, platform 직경 $3.6 \mathrm{~mm}$ 에 body 직경 $3.6 \mathrm{~mm}$ 의 3종류였다.

임플란트의 성공적인 골유착은 초기고정 및 bone remodeling에 의한 이차고정을 통해 이루어지게 되는데, 안정적인 초기고정은 이차고정과 밀접한 연관이 있다고 보고되어왔다. ${ }^{9-11}$ 따라서 임플란트의 성공적인 골유착을 예측하기 위해 초기고정에 대한 평가를 시행하는 것은 필수적이라 할 수 있다.

초기고정량을 측정하는 다양한 방법 중 Meredith 등 ${ }^{12}$ 이 소개한 공명진동수 분석법(resonance frequency analysis, $\mathrm{RFA}$ )은 오차범위 $1 \%$ 미만의 안정적인 방법으로 metal $\mathrm{peg}$ 를 임플란트와 결체 시켜 공명진동수를 측정하는 것으로 3500 - $8500 \mathrm{kHZ}$ 의 범위로 측정되는데, OSSTELL $^{\circledR}$ (Integration Diagnostics AB, Savedalen, Sweden)을 통해 implant stability quotient (ISQ)로 변환되어 나타나며 1 - 100의 지수로 표현된다. ${ }^{13}$ 식립된 임플란트 가 55 이하의 지수를 나타내는 경우 너무 많은 측방 움직 임을 나타낼 수 있다는 뜻으로, 보철물의 연결 전 추가적 인 고정력을 얻어야 함을 나타낸다고 보고되었다. ${ }^{14}$

본 연구에서는 단국대학교 치과대학 부속 치과병원 치 주과에서 식립한 $3.6 \mathrm{~mm}$ 이하의 좁은 직경의 임플란트 의 일정 기간의 생존율을 초기고정 값과 방사선학적 계 측을 통해 분석해보고자 하였다.

\section{연구 재료 및 방법}

\section{1. 연구 대상}

이번 연구는 2014년 2월부터 2015년 3월까지 단국대 학교 치과병원 치주과에서 직경 $3.6 \mathrm{~mm}$ 이하의 임플란 트를 식립한 환자를 대상으로 진행하였다. 18세 미만, 정 신이상, 조절되지 않는 당뇨, 면역 억제제 복용, 골다공증 치료를 위한 bisphosphonate 계열 약물 복용, 두경부 방 사선 치료 기왕력, 갑상선 질환, 이 악물기, 이갈이 등의 구강 이상 습관, 임신, 인접치의 치료되지 않은 치주염을 갖는 환자들은 제외하였으며, 위 조건에 부합되는 환자 들 중 술 후 1 년 이상의 정기적 내원을 한 24 명의 환자에 식립된 38개의 임플란트를 조사하였다. 임플란트의 직경 은 $3.6 \mathrm{~mm}$ 이하, 길이는 $7 \mathrm{~mm}$ 이상으로 제한하였다. 환 자의 나이 분포는 19 - 79세(평균 $50.6 \pm 15.43$ 세)로 남성 15 명, 여성 9 명의 비율로 구성되었다.

\section{2. 연구 방법}

식립된 임플란트의 platform 직경, body 직경, 길이, 식립 부위 등을 확인하였고 식립 시 골유도재생술의 동 반 시행 여부, 완성된 보철의 형태를 확인하였다. 초기고 정 값은 임플란트 식립 직후 측정한 ISQ 값을 확인하였 고, 치근단 방사선 사진을 통해 식립된 임플란트의 근 원 심 marginal bone level (MBL)을 방사선 계측 프로그램 (PACSPLUS viewer, Medical Standard Co., Ltd., Seoul, Korea)을 이용하여 측정하였다. 임플란트 생존율은 Buser 등이 제시한 기준을 따라 평가하였다. 1) 단일 임 플란트에서 압력을 주었을 때 동요도가 없을 것 2) 치근 단 방사선 사진 상 임플란트 주위에 연속적인 방사선 투 과상이 없을 것 3) 통증이나 감염 등의 지속적이고 비 가 역적인 증상 징후가 없을 것. ${ }^{3,15,16}$ 생존한 임플란트는 마 지막 follow up시의 치근단 방사선 사진을 통해 MBL의 변화를 계측하였고 골유도재생술 시행여부, 완성된 보철 물의 형태 등을 확인하였다. 실패한 임플란트는 생존기 간, 제거원인, 골유도재생술 시행 여부, 완성된 보철물의 형태에 따라 분석하였다.

\section{결과}

사용된 임플란트의 직경은 platform 직경 $3.2 \mathrm{~mm}$ 에 
body 직경 $3.1 \mathrm{~mm}$ (3.2), platform 직경 $3.6 \mathrm{~mm}$ 에 body 직경 $3.1 \mathrm{~mm}(3.6 \mathrm{w})$, platform 직경 $3.6 \mathrm{~mm}$ 에 body 직 경 $3.6 \mathrm{~mm}$ (3.6s) 이었고, 길이는 7, 9, $11 \mathrm{~mm}$ 의 3종류로 Table 1에 정리되어 있다. 상악 18 개, 하악 20개가 식립 되었으며 전치 25개, 견치 7 개, 소구치 6개로 부위에 따른 분포는 Table 2 와 같다. 골유도재생술을 동반한 경우는 17 개 였으며, 보철의 형태는 단일치 수복 13 개, cantilever 3개, Bridge 15개, Overdenture (OVD) 4개로 나타났다. 전체 임플란트의 생존율은 $92.11 \%$ 이었고 ISQ값의 범위 는 32 - 81, 평균 66.26으로 나타났다. 생존한 임플란트의 수술 후 follow up 기간은 평균 38.91개월이었고 ISQ 평 균값은 66.28, MBL 변화는 평균 $0.14 \pm 0.31 \mathrm{~mm}$ 를 나 타내었다. 실패한 임플란트는 총 3개였으며, 생존기간은 1 - 5개월로 평균 2.67개월이었고 ISQ값은 53 - 80으로 평균값은 66으로 나타났다. 실패한 임플란트 중 3.6w 형 태는 없었으며 각각의 제거 원인으로는 잔존 치근 제거 후 즉시식립에 따른 해당 부위 감염, 낮은 초기고정값, 원 인 미상 등 이었다. 실패한 임플란트들은 모두 보철물을 장착하기 전에 동요도가 확인되어 제거되었다. 실패한 임 플란트의 직경, 길이, 생존기간, 초기고정값, 골유도재생 술 시행 여부, 제거 원인 등을 Table 3에 정리하였다.

Table 1. Diameter and length of narrow diameter implants

\begin{tabular}{llrrrc}
\hline & & \multicolumn{4}{c}{ Length $(\mathrm{mm})$} \\
& & 7 & 9 & 11 & Total \\
\hline \multirow{2}{*}{ Diameter } & 3.2 & 0 & 6 & 0 & 6 \\
$(\mathrm{~mm})$ & $3.6 \mathrm{w}$ & 2 & 7 & 0 & 9 \\
& $3.6 \mathrm{~s}$ & 7 & 12 & 4 & 23 \\
\hline
\end{tabular}

$3.6 \mathrm{w}: 3.6 \mathrm{~mm}$ platform diameter, $3.1 \mathrm{~mm}$ body diameter implants. 3.6s: $3.6 \mathrm{~mm}$ platform diameter, $3.6 \mathrm{~mm}$ body diameter implants.

\section{고찰}

본 연구는 $3.6 \mathrm{~mm}$ 이하의 좁은 직경 임플란트의 생존 율을 확인하기 위해 초기고정 값과 방사선 사진 상의 근 원심 MBL의 변화를 통하여 후향적으로 관찰한 것으로 $3.2,3.6 \mathrm{w}, 3.6 \mathrm{~mm}$ 직경의 임플란트에 대하여 조사하였 다. 다양한 원인으로 인한 좁은 근 원심 혹은 협 설측 폭 경을 갖는 치조골에서 표준 직경 임플란트 또는 넓은 직 경의 임플란트를 사용할 경우 열개(dehiscence)형태의 골 결손이 발생될 가능성이 높고 초기고정력이 약해지는 결과를 나타낼 수 있다. 이를 극복하기 위한 광범위한 골 유도재생술을 시행하게 되는데 이전 systemic review 연 구에 따르면 비흡수성 차폐막의 $20 \%$, 흡수성 차폐막의 $5 \%$ 에서 술 후 노출이 일어난다 조사되었다. ${ }^{2}$ 이번 연구 에서 1 개의 감염에 의한 실패가 있었으나, 이는 잔존 치 근의 감염이 있는 부위에 발치 후 즉시 식립에 따른 감염 으로 추정되며 이식된 골 또는 차폐막에 의한 감염으로 판단되지 않았다. 따라서 본 연구에서는 골유도재생술을 동반시행 한 17 개의 임플란트에서 차폐막 노출에 따른 감염에 의해 실패한 경우는 없었으며, 이는 좁은 직경 임 플란트를 사용함으로써 필요한 골유도재생술의 범위가

Table 2. Position of narrow diameter implants

\begin{tabular}{lcccc}
\hline Position & Anterior & Canine & Premolar & Total \\
\hline Maxilla & 12 & 2 & 4 & 18 \\
Mandible & 13 & 5 & 2 & 20 \\
Total & 25 & 7 & 6 & 38 \\
\hline
\end{tabular}

Table 3. Review of failure implants

\begin{tabular}{lccc}
\hline \multicolumn{1}{c}{ Implant } & Case 1 & Case 2 & Case 3 \\
\hline Diameter (mm) & $3.6 \mathrm{~s}$ & 3.2 & $3.6 \mathrm{~s}$ \\
Length (mm) & 7 & 9 & 9 \\
Survival period (month) & 1 & 5 & 2 \\
Initial stability (ISQ) & 65 & 53 & 80 \\
Guided bone regeneration & DBBM & X & X \\
Cause of failure & Infection & Poor initial stability & Unknown
\end{tabular}

3.6s: $3.6 \mathrm{~mm}$ platform diameter, $3.6 \mathrm{~mm}$ body diameter implants.

DBBM: Deproteinized bovine bone mineral. 
줄어들어 차폐막 노출 혹은 감염의 기회가 줄어든 것으 로 추정된다.

최근 다양한 연구에서 좁은 직경 임플란트의 생존율은 표준 직경 임플란트와 유의한 차이가 없다고 보고되고 있다. Zinsli 등 ${ }^{17}$ 은 $3.3 \mathrm{~mm}$ 직경 임플란트의 5년 누적 생 존율은 $98.7 \%$ 로 나타났다 보고하였고, Romeo 등 ${ }^{18}$ 의 연 구에서는 $3.3 \mathrm{~mm}$ 직경 임플란트를 $4.1 \mathrm{~mm}$ 의 표준 직경 임플란트와 비교했을 때 7년 누적 생존율이 각각 상악에 서 $98.1 \%$ 와 $96.8 \%$, 하악에서 $96.9 \%$ 와 $97.9 \%$ 로 유의한 차이가 없는 것으로 나타났다. 그러나 이번 연구에서 전 체 임플란트는 $92.11 \%$ 의 생존율을 보여 기존연구들보다 다소 낮게 나타났다. 이는 부족한 표본 수에 기인한 것으 로 판단된다. 그러나 $3.1 \mathrm{~mm}$ 의 body 직경과 $3.6 \mathrm{~mm}$ 의 platform 직경을 갖는 임플란트는 높은 생존율 $(100 \%)$ 을 나타내었다. 이는 emergency profile과 연관 지어 해 석할 수 있는데 $\mathrm{Misch}^{19}$ 는 결손 된 치아를 임플란트로 수 복 시 기존 자연치와 유사한 emergency profile을 재현해 야 하는데 이는 대상자연치 CEJ $2 \mathrm{~mm}$ 하방의 치근 직경 과 유사한 직경을 갖는 임플란트를 선택하는 것이 필요 하다 하였다. 또한 Yuodelis 등 ${ }^{20}$ 과 Reeves ${ }^{21}$ 는 보철물의 emergency profile을 올바르게 형성하는 것은 치태침착 뿐만 아니라 보철로 인한 의원성 치은염증을 감소시킨다 고 보고한바 있다. 따라서 $3.1 \mathrm{~mm}$ 의 body 직경이 부족한 골폭경을 갖는 부위에도 식립을 용이하게 하고 조직유 도재생술의 필요 범위가 줄어들어 부작용에 따른 실패를 줄일 뿐만 아니라 상대적으로 넓은 $3.6 \mathrm{~mm}$ 의 platform 직경이 적절한 emergency profile 형성하여 이상적인 형 태에 가까운 보철 형성 및 치태조절에 유리해지기 때문일 것으로 사료된다.

좁은 직경의 임플란트의 실패 원인에 대한 기존 연구 에서 Quek 등은 좁은 직경으로 인해 fixture의 wall과 abutment 및 screw가 얇아 파절되기 쉽다 보고하였고, Shemtov-Yona 등 ${ }^{22}$ 은 직경 $3.3 \mathrm{~mm}$ 직경의 좁은 임플란 트에서 screw 파절과 동시에 fixture의 2 번째 혹은 3 번째 thread의 파절이 관찰되었다고 보고하였다. Arisan 등 $^{23}$ 은 abutment의 표면과 접착 유지면적이 줄어들어 cement loosening을 일으키기 쉬우므로 인접 임플란트간 splint 형태의 보철을 시행할 것으로 권유하였다. 이번 연구에서 실패한 임플란트들은 모두 하중을 가하기 전 골 유착 실 패 또는 감염에 의한 것이었으며 하중을 가한 나머지 임 플란트에서는 이전 연구에서 보고된 문제점들이 나타나 지 않았다.
4개의 임플란트에서 OVD형태의 보철로 수복되었고 이들은 각각 2개의 임플란트만으로 지지하는 하악 OVD 형태였으며 36.5개월 간의 양호한 유지상태를 보였다. Romeo 등 ${ }^{24}$ 은 7 년간의 후향적 연구에서 2 개 임플란트 지지 OVD는 3개 이상의 임플란트 지지 OVD와 생존율 에서 비슷한 결과를 나타내었다 하였고, Zinsli 등 ${ }^{17}$ 은 3.3 $\mathrm{mm}$ 직경의 straumann 임플란트를 후향적으로 관찰한 연구에서 좁은 직경의 임플란트는 OVD를 지지하기에 충분하다고 결론 내린 바 있다. 이전의 연구들과 본 연구 의 결과로 미루어 보았을 때, 2 개의 좁은 직경의 임플란 트로도 OVD 지지가 가능할 것으로 판단된다.

연구 기간동안 생존한 임플란트의 일부에서 평균 0.14 $\mathrm{mm}$ 의 MBL의 변화가 관찰되었다. 임플란트 주위염으 로 인해 fixture의 골 소실이 관찰될 수도 있으나 ${ }^{25}$ 이들 중 감염 및 동요도 등의 문제를 나타내는 임플란트는 없 었다. 또한 연구에 사용된 임플란트에 대한 제조사의 소 개에 따르면 fixture의 상부를 hybrid zone으로 형성하였 는데, 이는 bone contact 또는 soft tissue attachment를 모두 허용할 수 있도록 제작되었다 설명하였다. 계측된 MBL의 변화 범위가 해당 hybrid zone 내에 위치되었고, 성공 기준에도 벗어나지 않았으므로 성공으로 판단하였 으나 주기적인 관찰이 필요 것으로 사료된다.

이번 연구의 한계점으로는 첫번째, 2 차원적인 치근단 방사선 사진을 이용하여 $\mathrm{MBL}$ 을 평가한 것이다. 이는 근 원심의 MBL만 파악 가능하며 협 설측 $\mathrm{MBL}$ 은 계측이 불가능하다. 추후 진행될 연구에서는 CBCT 등을 이용 한 삼차원적인 계측이 필요할 것으로 사료된다. 둘째로 적은 표본수로 인해 기존연구보다 낮은 전체 임플란트 생존율과 $3.6 \mathrm{~mm}$ platform의 $3.1 \mathrm{~mm}$ body 직경의 임플 란트의 높은 생존율, 또한 2개의 임플란트 지지 OVD에 서의 성공적인 예후 등의 결과를 예지성 있게 신뢰하기는 부족하다. 더 많은 표본 수를 통한 추후 연구를 통해 더 욱 신뢰도를 높일 수 있는 연구가 필요할 것으로 사료된 다.

\section{결론}

이번 연구에서 조사한 결과 다음과 같은 결론을 내렸다.

1. 좁은 직경 임플란트의 3년 생존율은 $92.11 \%$ (35/38 개)였다.

2. Platform 직경을 body 직경보다 크게 만든 형태의 임플란트는 높은 생존율을 보였다. 
3. 하중을 받아 생기는 파절, screw 풀림 등의 문제는 발생되지 않았고 2개의 좁은 임플란트 지지 overdenture 형태의 보철에서도 양호한 결과를 나타내 었다.

위의 결과로 미루어 보아 좁은 직경의 임플란트는 좁 은 직경의 치조제에 안정적인 치료 결과를 나타낸다 사 료된다.

\section{ORCID}

Sung-Jo Lee https://orcid.org/0000-0002-7834-209X

Sae-Young Jung https://orcid.org/0000-0002-49267254

Hyun-Seung Shin https://orcid.org/0000-0002-14109731

Jung-Chul Park https://orcid.org/0000-0002-20418047

Young-Gyun Song https://orcid.org/0000-0003-37899585

In-Woo Cho https://orcid.org/0000-0003-4985-3816

\section{References}

1. Jung RE, Fenner N, Hämmerle CH, Zitzmann NU. Long-term outcome of implants placed with guided bone regeneration (GBR) using resorbable and non-resorbable membranes after 12-14 years. Clin Oral Implants Res 2013;24:1065-73.

2. Chiapasco M, Zaniboni M. Clinical outcomes of GBR procedures to correct peri-implant dehiscences and fenestrations: a systematic review. Clin Oral Implants Res 2009;20 Suppl 4:113-23.

3. Buser D, Mericske-Stern R, Bernard JP, Behneke A, Behneke N, Hirt HP, Belser UC, Lang NP. Longterm evaluation of non-submerged ITI implants. Part 1: 8-year life table analysis of a prospective multi-center study with 2359 implants. Clin Oral Implants Res 1997;8:161-72.

4. Bornstein MM, Schmid B, Belser UC, Lussi A, Buser D. Early loading of non-submerged titanium implants with a sandblasted and acid-etched surface. 5 -year results of a prospective study in partially edentulous patients. Clin Oral Implants Res 2005;
16:631-8.

5. Klein MO, Schiegnitz E, Al-Nawas B. Systematic review on success of narrow-diameter dental implants. Int J Oral Maxillofac Implants 2014;29 Suppl:43-54.

6. Davarpanah M, Martinez H, Tecucianu JF, Celletti R, Lazzara R. Small-diameter implants: indications and contraindications. J Esthet Dent 2000;12:18694.

7. Quek CE, Tan KB, Nicholls JI. Load fatigue performance of a single-tooth implant abutment system: effect of diameter. Int J Oral Maxillofac Implants 2006;21:929-36.

8. Osman RB, Swain MV. A critical review of dental implant materials with an emphasis on titanium versus zirconia. Materials (Basel) 2015;8:932-58.

9. Davies JE. Mechanisms of endosseous integration. Int J Prosthodont 1998;11:391-401.

10. Greenstein G, Cavallaro J, Romanos G, Tarnow D. Clinical recommendations for avoiding and managing surgical complications associated with implant dentistry: a review. J Periodontol 2008;79:1317-29.

11. Natali AN, Carniel EL, Pavan PG. Investigation of viscoelastoplastic response of bone tissue in oral implants press fit process. J Biomed Mater Res B Appl Biomater 2009;91:868-75.

12. Meredith N, Alleyne D, Cawley P. Quantitative determination of the stability of the implant-tissue interface using resonance frequency analysis. Clin Oral Implants Res 1996;7:261-7.

13. Konstantinović VS, Ivanjac F, Lazić V, Djordjević I. Assessment of implant stability by resonant frequency analysis. Vojnosanit Pregl 2015;72:169-74.

14. Suzuki S, Kobayashi H, Ogawa T. Implant stability change and osseointegration speed of immediately loaded photofunctionalized implants. Implant Dent 2013;22:481-90.

15. Buser D, Weber HP, Lang NP. Tissue integration of non-submerged implants. 1-year results of a prospective study with 100 ITI hollow-cylinder and hollow-screw implants. Clin Oral Implants Res 1990;1:33-40.

16. Buser D, Mericske-Stern R, Dula K, Lang NP. Clinical experience with one-stage, non-submerged dental implants. Adv Dent Res 1999;13:153-61. 
17. Zinsli B, Sägesser T, Mericske E, Mericske-Stern R. Clinical evaluation of small-diameter ITI implants: a prospective study. Int J Oral Maxillofac Implants 2004;19:92-9.

18. Romeo E, Lops D, Amorfini L, Chiapasco M, Ghisolfi M, Vogel G. Clinical and radiographic evaluation of small-diameter (3.3-mm) implants followed for 1-7 years: a longitudinal study. Clin Oral Implants Res 2006;17:139-48.

19. Misch CE. Contemporary implant dentistry. 3rd ed. St. Louis; Mosby; 2008. p. 1120.

20. Yuodelis RA, Weaver JD, Sapkos S. Facial and lingual contours of artificial complete crown restorations and their effects on the periodontium. J Prosthet Dent 1973;29:61-6.

21. Reeves WG. Restorative margin placement and periodontal health. J Prosthet Dent 1991;66:733-6.
22. Shemtov-Yona K, Rittel D, Machtei EE, Levin L. Effect of dental implant diameter on fatigue performance. Part II: failure analysis. Clin Implant Dent Relat Res 2014;16:178-84.

23. Arisan V, Bölükbaşi N, Ersanli S, Ozdemir T. Evaluation of 316 narrow diameter implants followed for 5-10 years: a clinical and radiographic retrospective study. Clin Oral Implants Res 2010;21:296-307.

24. Romeo E, Lops D, Margutti E, Ghisolfi M, Chiapasco M, Vogel G. Long-term survival and success of oral implants in the treatment of full and partial arches: a 7-year prospective study with the ITI dental implant system. Int J Oral Maxillofac Implants 2004;19:247-59.

25. Mombelli A, Lang NP. The diagnosis and treatment of peri-implantitis. Periodontol 2000 1998;17:6376. 


\section{좁은 직경 임플란트 3년간의 생존율에 관한 후향적 연구}

\section{이성조 ${ }^{1}$, 정세영 ${ }^{1}$, 신현승 ${ }^{*}$, 박정철 ${ }^{1}$, 송영균 ${ }^{2}$, 조인우 ${ }^{1}$}

${ }^{1}$ 단국대학교 치과대학 치주과학교실

${ }^{2}$ 단국대학교 치과대학 보철학교실

목적: $3.6 \mathrm{~mm}$ 이하 좁은 직경 임플란트의 일정 기간 생존율을 초기고정 값과 방사선학적 계측을 통해 분석해보고자 하였다. 연구 재료 및 방법: 24 명의 환자에 식립된 직경 $3.6 \mathrm{~mm}$ 이하, 길이 $7 \mathrm{~mm}$ 이상의 38 개의 임플란트를 조사하였다. 식립된 임플란트의 platform 직경, body 직경, 길이, 식립 부위 등을 확인하였고 식립 시 골유도재생술의 동반 시행 여부, 완성된 보철의 형태를 확인하였다. 초기고정 값은 임플란트 식립 직후 측정한 implant stability quotient (ISQ) 값을 확인하였고, 방사선 사진을 통해 식립된 임플란트의 근 원심 marginal bone level (MBL)을 측정하였다.

결과: 전체 임플란트의 생존율은 $92.11 \%$ 이었고 ISQ값은 평균 66.26 으로 나타났다. 생존한 임플란트의 MBL 변화는 평 균 $0.14 \pm 0.31 \mathrm{~mm}$ 를 나타내었다. Platform 직경이 body 직경보다 큰 임플란트 중 실패한 임플란트는 없었다.

결론: 좁은 직경의 임플란트는 좁은 직경의 치조제에 안정적인 치료 결과를 나타낸다 사료된다.

(구강회복응용과학지 2018;34(1):32-8)

주요어: 좁은 직경 임플란트; 생존율; 자기공명주파수분석법

*교신저자: 신현승

(31116) 충남 천안시 동남구 단대로 119 단국대학교 치과대학 치주과학교실

Tel: 041-550-0263 | Fax: 0303-3442-7364 | E-mail: perioshin@dankook. ac. kr

접수일: 2017년 11월 24일 | 수정일: 2017년 11월 27일 | 채택일: 2018년 1월 2일 